Research Article: Education

\title{
Strengths and Challenges of Distance Learning Modalities in the New Normal: Basis for Intervention Program
}

\section{Laura R. Hernandez ${ }^{1}$}

\section{${ }^{1}$ Department of Education - Jose J. Mariano Memorial High School, Bintog, Plaridel. Bulacan, Philippines.}

\section{Article History \\ Received: \\ 21.07.2021}

Revised:

08.08.2021

Accepted:

12.08 .2021

*Corresponding Author:

Laura R. Hernandez

Email:

laura.hernandez@deped.gov.ph

This is an open access article, licensed under: $C C-B Y-S A$
Abstract: The study was conducted to identify the strengths and challenges of distance learning modalities as a basis for intervention programs from a memorial high school in a schools' division in Bulacan, Philippines. The researcher used a descriptive survey type of study. For the sample of the study, it employed eight (8) teachers and 39 learners from a junior high school chosen randomly. A self-made checklist survey questionnaire was created by the researcher which was validated by a panel of experts. Descriptive statistics were used to analyze the collected data with the help of a Microsoft Excel sheet. Results revealed that teachers and learners have a variety of strengths in distance learning modalities. In addition, teachers and learners also stressed the different challenges they encountered for distance learning modalities. Based on these findings of the study, the researcher used them for a possible formulation of an intervention program that aimed to providing solutions for the challenges of distance learning and also enhancing the strengths for both the teachers and learners.

Keywords: Distance Learning Modalities, Intervention Program, New Normal, Strengths and Challenges. 


\section{Introduction}

Distance Education (DE) is an alternative way of educating learners, especially in today's world. DE across all levels in education is growing at a rapid rate [1]. It is nowadays defined more as Open and Distance Learning which uses non-traditional approaches and delivery methods compared to campusbased education [2]. The education system in the Philippines shifted from face-to-face to distance learning modes of learning modalities. This calls for the paradigm shift of schools to offer different platforms but the same level of competency and understanding.

The Department of Education (DepEd) issued an Order to follow in terms of the Basic Education Learning Continuity Plan for School Year 2021 in Light of the Covid-19 Public Health Emergency which says no face-to-face classes until safe. It also states that DE refers to a learning delivery modality where learning takes place between the teacher and the learners who are geographically remote from each other during instruction [3]. This year, the schools offer different learning modalities namely: Modular Distance Learning (MDL); Online Distance Learning (ODL); and Television (TV)/Radio-Based Instruction. These are different platforms that learners chose based on the surveys conducted by the schools before the opening of classes last October 2020.

Moreover, different online learning platforms are also considered useful for teaching and learning engagement. This learning modality will be the main focus of the study on how to face the strengths and perceptions of the select teachers and learners from memorial high school. Thus, the urgent needs of educators and learners evolve when considering the quality of instructions. It is crucial to understand and get a deeper insight into trends and issues in DE to keep abreast of these constant changes. These are some of the propelling issues that the researcher would like to know.

The main objective of this study is to determine the strengths and challenges encountered by teachers and learners from a memorial high school in the province of Bulacan, Philippines, with the use of distance learning modalities for this School Year 2020-2021. The result of the study will become a basis for an intervention program of the school.

\section{Literature Review}

Education must continue and that is why, the DepEd continuously monitors each school process to secure the constitutional mandates of the agency, to educate each learner through efficient procurement processes of resources [3]. Distance Education may seem very significant nowadays, specifically to those learners who can't go to school for their face-to-face class. Hence, this significant factor has uncertainties as regards to the misuse of the technology, the attitudes of learners, since students tend to procrastinate [4] and bully teachers [5] [6] [7], administrators' behavior and competencies [8] [9] and most of all the quality of instructions [10] [11]. According to another study students perceived distance education as a road to dreams and they thought it provided them to study while working in a job [12].

In these challenging times that arise common problems and issues amidst the pandemic of COVID - 19, the setback of initiating teaching-learning will be in the mode of learning modules for distance education. In a related study where an author identified the impact of contextualized elearning resources on the performance of students and yielded a positive result [13]. Also, another study mentioned that schools are not yet prepared for distance learning [8]. Due to this reason, different modalities will be given consideration aside from giving the learners learning modules. Another researcher offered some ideas regarding the different learning modalities for various avenues for learners [14]. Furthermore, internet connections and learning device availability also great issues among teachers and students [15].

Operationalization of digitized modular learning modality has been crafted to better secure the health safety of everyone as to Inter-Agency Task Force (IATF) and Department of Health (DOH) protocols. But these topics became an issue amongst parents and learners as to how these distance learning modalities will be implemented and manifested while everyone is still threatened by the virus outside and compliance to a disaster like this pandemic can be an issue [16] [17].

With the different perspectives among authors mentioned in the discussion opted the researcher to do this study and give light on the strengths and challenges that confront distance learning modality among teachers and learners. 


\section{Methodology}

\subsection{Research Design}

In this study, the researcher used a descriptive type of research design. Descriptive research describes the characteristics of a population that is being studied. This study investigates the strengths and challenges of distance learning as regards the quality of instructions of the selected teachers and learners, thus the said research design fits.

\subsection{Respondents}

The population of this study was 195 junior high school learners and 36 junior high school teachers from a memorial high school in the province of Bulacan, the Philippines for the school year 20202021. To determine the number of participants, the researcher used a simple sampling technique to give equal opportunity to all possible participants. This paved way to have representatives from different subject areas for teachers and learners from different sections. To summarize, there were a total of eight (8) from the 36 junior high school teachers, and 39 learners from 195 were selected.

\subsection{Research Instrument}

For the survey instrument, the researcher developed one following the aim of this study. In addition, the survey questionnaires were validated by the Education Program Supervisor, School Principal, Master Teacher, Head Teacher, and Teacher to properly check the validity of the questionnaires. Meanwhile, the questionnaires were pilot tested on the participants who are not subjects of the study.

\subsection{Ethical Considerations}

This study considered the following ethical issues before the administration of the actual survey. The participants were not subjected to anyway or form of harm. Full consent from the participants was obtained before answering the survey. The participants were not forced or harmed in any way if they refuse to answer the survey. The researcher also made sure that all the data gathered were treated in full confidentiality and privacy was observed at all times. The researcher also ensured the anonymity of individuals and organizations who participated in the survey. Conflict of interests and any forms of affiliation and sources of funding were declared by the researcher. And any type of communication about the research was done in full honesty and transparency.

\subsection{Data Analysis}

The data gathered were tabulated using the Microsoft Excel sheet. Then, the researchers subjected the gathered data to statistical analysis for proper treatment and interpretation. This study used three basic descriptive statistical tools namely, rank, frequency count, and percentage.

\section{Results and Discussion}

This section presents the analysis and interpretation of all the data gathered for this study following the problems presented. It looked into the strengths and challenges of distance learning modalities under new normal. Likewise, it also looked into the crafting of an intervention program for teachers and learners to improve teachers' proficiency and learners' academic performance.

Table 1 shows the 14 strengths of distance learning modalities encountered by teachers. As seen from the presentation, "It provides flexible time" garnered the highest possible frequency of responses among the teachers. It also ranks first among the other strengths mentioned in the survey. On the other hand, "It gives more chances to contextualized materials" got the lowest rank since it also has the least responses among the group. The result of this study revealed that teachers gained positive attributes during distance learning modalities. According to them during the survey, they have more time to balance the work-related and home-related activities due to the limited number of days to physically report at school. Although the covid-19 virus continuously threatens everyone, distance learning modalities gave them the sense of safety and security to free from viruses. This gain brings the positive result to teacher concentration and availability to perform their duties and function as classroom teachers.

This study is parallel to the study conducted by Akilli and Keskin [18] that the extrinsic variable has a negatively significant relationship with the intrinsic and altruistic variables, while a positively significant relationship with the mercenary variable. This means that the data from the measurement model in which the interrelationship of the latent variables was seen that the intrinsic and extrinsic 
factors have an impact across the motivational processes which are effective with the preference of the teaching profession.

Table 1. Strengths of Distance Learning Modalities in New Normal Encountered by Teachers

\begin{tabular}{lccc}
\hline Strengths & Rank & $\boldsymbol{f}^{*}$ & \% \\
\hline It provides flexible time. & 1 & 8 & 100.0 \\
It is accessible to all. & 2.5 & 6 & 75.00 \\
It helps to have constant open communication amongst learners. & 2.5 & 6 & 75.00 \\
It emphasizes the importance of normal education. & 5 & 5 & 62.50 \\
It saves time to travel going to school. & 5 & 5 & 62.50 \\
It gives a sense of security from accidents. & 5 & 5 & 62.50 \\
It gains strong parents' support. & 8 & 4 & 50.0 \\
It increases technological intelligence. & 8 & 4 & 50.00 \\
It lessens the travel expenses. & 8 & 4 & 50.00 \\
It provides different teaching options and platforms. & 11.5 & 3 & 37.50 \\
It promotes multi-tasking. & 11.5 & 3 & 37.50 \\
It easily helps to participate and access international and local & 11.5 & 3 & 37.50 \\
training/seminars. & 11.5 & 3 & 37.50 \\
It promotes the collaboration of materials amongst teachers. & 14 & 2 & 25.00 \\
It gives more chances to contextualized materials. & & & \\
\hline *h & & &
\end{tabular}
$*_{n}=8$

Table 2 presents the 11 strengths enumerated by the learner-respondents in distance learning modalities. Based on the presentation, "It saves time to travel to school" got the highest frequency and rank among the learner-respondents of the study. However, "It promotes multitasking" got the lowest rank and frequency. The result of this study encompasses that learners have more time to perform tasks in their respective houses. Accordingly, students feel they are not in a hurry to perform scholastic activities and performance tasks, especially in the printed modular modality. Learners also can discover one's talent and try to use expose themselves to different methods in each lesson makes them tolerable to think of necessary ways and processes in solving problems. Distance learning also enhances ICT skills and exploration of collaborative knowledge strengthens and equips them because technological platforms are available.

Table 2. Strengths of Distance Learning Modalities in New Normal Encountered by Learners

\begin{tabular}{lccc}
\hline \multicolumn{1}{c}{ Strengths } & Rank & $\boldsymbol{f}^{*}$ & $\mathbf{\%}$ \\
\hline It saves time to travel to school. & 1 & 39 & 100.0 \\
It offers flexible time. & 2 & 38 & 97.45 \\
It encourages supports from parents. & 3 & 37 & 94.87 \\
It saves money for daily allowance. & 4.5 & 36 & 92.31 \\
It gives a sense of security when at home. & 4.5 & 36 & 92.31 \\
It provides different learning platforms. & 6 & 34 & 87.18 \\
It emphasizes the importance of education. & 7 & 32 & 82.05 \\
It is accessible. & 8 & 31 & 79.49 \\
It promotes multitasking. & 9 & 30 & 76.92 \\
It develops independence. & 10 & 26 & 66.67 \\
In times of illness, no need to go to school to learn. & 11 & 17 & 43.59 \\
\hline
\end{tabular}

$*_{n}=39$ 
This is connected to the study conducted by Simulwi and Musonda [19] which established the introduction of ICT as a compulsory subject has an impact on teacher and pupil literacy. This explains that the integration of technological advancement brings clearer perceptions about the lesson especially today. The same perspective was introduced by another study regarding the ICT skills assessment of teachers and its impact on their teaching profession [20].

Table 3. Challenges of Distance Learning Modalities in New Normal Encountered by Teachers

\begin{tabular}{lccc}
\hline \multicolumn{1}{c}{ Challenges } & Rank & $\boldsymbol{f}^{*}$ & $\mathbf{\%}$ \\
\hline Lack of focus due to work-related and home-related activities at home. & 1 & 8 & 100.0 \\
Additional expense for internet load. & 2 & 7 & 87.50 \\
Worries during distribution and retrieval of modules. & 4.5 & 6 & 75.00 \\
Additional purchase of gadgets or technological equipment for new & 4.5 & 6 & 75.00 \\
normal. & 4.5 & 6 & 75.00 \\
Pushes to become digital natives. & 4.5 & 6 & 75.00 \\
Unrealistic answers of modules for academic records. & 7.5 & 5 & 62.50 \\
Delimit scope of authority in the class. & 7.5 & 5 & 62.50 \\
Delimit social development and interaction. & 9 & 4 & 50.00 \\
Loosened disciplines of learners. & 10 & 3 & 37.50 \\
No available space for privacy. & & &
\end{tabular}

Table 3 shows the ten (10) challenges enumerated by the teacher-respondents in distance learning modalities. As seen, "Lack of focus due to work-related and home-related activities at home" garnered the highest frequency and rank among the enumerated challenges by the teacher-respondents. But, "No available space for privacy gathered the lowest rank and frequency among the group. This result only shows the different and unexpected impact of distance learning on teachers. It affects them physically, emotionally, mentally, and socially in many aspects. Here it only revealed shrivel of the most common dilemmas that compound their everyday lives as teachers.

The result of the current study somehow agrees with another study which analyzed the mental health and stress level of teachers in terms of developing learning resources [21]. In addition, Riego de Dios [22] also mentioned in her study regarding the work ethics of teachers which are essential for them.

Table 4. Challenges of Distance Learning Modalities in New Normal Encountered by Learners

\begin{tabular}{lccc}
\hline \multicolumn{1}{c}{ Challenges } & Rank & $\boldsymbol{f}^{*}$ & $\mathbf{\%}$ \\
\hline It is an additional expense to the family especially the internet load. & 1 & 35 & 89.74 \\
Limited learning opportunities. & 2 & 34 & 87.18 \\
It does not promote social development. & 3 & 32 & 82.05 \\
Unavailability during online classes. & 4 & 29 & 74.36 \\
The technology may be misused. & 5 & 28 & 71.79 \\
Dishonesty is due to the answer key page in the modules. & 6 & 27 & 69.23 \\
Hassle to parents during weekly retrieval and returning of modules. & 7 & 20 & 51.28 \\
No available space for privacy. & 8 & 17 & 43.59 \\
For working parents/do not possess the subject competence, insufficient & 9 & 15 & 38.46 \\
guidance, and assistance of a parent. & & &
\end{tabular}

$*_{n}=39$ 
Table 4 presents the nine (9) challenges of distance learning modalities encountered by learnerrespondents. The table displays that "It is an additional expense to the family especially the internet load" yielded the highest rank and frequency in the survey. Conversely, "For working parents/ do not possess the subject competence, insufficient guidance and assistance of parent" produced the lowest rank and frequency among the set. The result of the research conducted reveals the challenges encountered by teachers and learners in distance learning modalities. These challenges call for better teaching-learning strategies of the teachers and a stronger model of operational processes of the school to encapsulate the learners' mastery of competencies through different learning platforms.

This was strengthened by the study conducted by Arnold and Ducate [23] where they stressed that there is no one right way of doing things-what is effective and appropriate teaching, it depends to a large extent on a wide variety of contextual factors which play an important role in determining the extent to which teachers can implement instruction congruent with the learner's cognition. Additionally, the results also are intended for professional development among teachers [24], together with their work attitude, values, and performance [22] [25].

\section{Conclusion}

Teachers and learners on distance learning modalities provides them flexible time, access to all, helps to have constant open communication amongst them, emphasis on the importance of normal education, saves time to travel going to school, gives a sense of security from accidents, gain strong parents' support, increases technological intelligence, lessens travel expense, provides different teaching options and platforms, promotes multi-tasking, helps to participate and access in international and local trainings/seminars, promotes collaboration of materials amongst teachers and givers more chances to contextualized materials while learners encountered that distance learning modalities saves their time to travel to school, offers flexible time, encourages supports from parents, saves money for daily allowance, gives a sense of security when at home, provides different learning platforms, emphasizes the importance of education, accessible, promotes multitasking, develops independence, and in times of illness, no need to go school to learn.

Meanwhile, teachers stressed the challenges brought about by distance learning modalities under new normal education. These were lack of focus due to work-related and home-related activities at home, additional expense for internet load, worries during distribution and retrieval of modules, an additional purchase of gadgets or technological equipment for new normal, pushes them to become digital natives, unrealistic answers of modules for academic records, delimit the scope of authority in the class and social development and interaction, loosens disciplines of learners, and no available space for privacy. Among those challenges, learners also listed the following: additional expense to the family especially the internet load, limited learning opportunities, does not promote social development, unavailability during online classes, technology may be misused, dishonesty due to answer key page in the modules, hassle to parents during weekly retrieval and returning of modules, no available space for privacy, and insufficient guidance and assistance of parent in subject competence required.

In the light of the conclusion drawn, the following recommendations are hereby offered by the researcher:

1. Teachers should learn to maximize and prioritize work simplification to attain proper time management and work-life balance especially during work-from-home scheme;

2. Teachers should reprogram their budget management from traveling expenses to internet load to sustain their attendance during online training, webinar, or meeting;

3. Teachers should understand that increasing technological competence requires better and up-to-date equipment/devices to strengthen themselves in ICT through training and workshop which will hone their skills in different technological platforms in teaching and learning;

4. Teachers should have continuous innovation and development mechanisms that will help every learner to master different learning competencies despite public health emergencies;

5. Teachers and parents should always observe health protocols especially when outside the house to safeguard security from viruses;

6. Parents may use other learning modalities particularly the digitized learning modality and blended learning modality to avoid additional internet expense and lessen the physical appearance in school; 
7. Parents should have time to assist their children in doing school-related activities to promote honesty, integrity, and social interaction amongst members of the family;

8. Parents should designate a schedule for their children in doing school-works and household tasks to avoid disturbance and promote privacy;

9. School heads should help teachers through Learning and Development (L \& D) Plan to include capacity building on the different important topics concerning health issues, ICT advancement, and stakeholders' linkages and partnerships;

10. School heads should include Personal Protective Equipment (PPE) supplies and materials of teachers for procurement under Maintenance and Other Operating Expenses (MOOE); and

11. Education Program Supervisors may use this study as a springboard in developing programs, activities, and projects for implementation in their respective subject areas.

\section{References}

[1] "Creating Better Definitions of Distance Education," Online Journal of Distance Learning Administration. [Online]. Available: https://www.westga.edu/ distance/ojdla/summer232/ johnston232.html. [Accessed: 20-Jul-2021].

[2] A. Saykili, "Distance Education: Definitions, Generations, Key Concepts and Future Directions.," International Journal of Contemporary Educational Research, 31-May-2018. [Online]. Available: https://eric.ed.gov/?id=EJ1207516. [Accessed: 20-Jul-2021].

[3] Anynomuous, "June 19, 2020 DO 012, 2020 - Adoption of the Basic Education Learning Continuity Plan for School Year 2020-2021 in the Light of the COVID-19 Public Health Emergency," Department of Education. [Online]. Available: https://www.deped.gov.ph/ 2020/06/19/june-19-2020-do-012-2020-adoption-of-the-basic-education-learning-continuityplan-for-school-year-2020-2021-in-the-light-of-the-covid-19-public-health-emergency/. [Accessed: 20-Jul-2021].

[4] J. M. Asio, "The Relationship between Academic Procrastination and Academic Performance of Freshmen Students from a Teacher Education Institution," Journal of Humanities and Social Sciences, vol. 2, no. 3, pp. 105-115, 2020. https://doi.org/10.36079/lamintang.jhass-0203.156

[5] J. M. Asio, "Students bullying teachers: Understanding and behavior of college students from a higher education institution," Journal of Pedagogical Research, vol. 3, no. 2, pp. 11-20, 2019.

[6] J. M. R. Asio and E. D. Gadia, "Awareness and Understanding of College Students" [Online]. Available: https://files.eric.ed.gov/fulltext/ED595107.pdf. [Accessed: 20-Jul-2021].

[7] J. M. R. Asio and E. D. Gadia, "Students' perception of instructor bullying in a local college in Zambales, Philippines." [Online]. Available: https:/files.eric.ed.gov/fulltext/ED600562.pdf. [Accessed: 20-Jul-2021].

[8] J. M. R. Asio and S. A. Bayucca, "Spearheading education during the COVID-19 rife: Administrators level of digital competence and schools readiness on distance learning," Journal of Pedagogical Sociology and Psychology, vol. 3, no. 1, pp. 19-26, 2021.

[9] E. C. Jimenez, "Adversity and emotional quotients of public elementary school heads amidst the COVID-19," International Journal of Didactical Studies, vol. 2, no. 2, pp. 101460-101460, 2021.

[10] J. M. R. Asio and E. E. Riego de Dios, "21st Century Attributes and Skills" [Online]. Available: https://files.eric.ed.gov/fulltext/ED594675.pdf. [Accessed: 20-Jul-2021].

[11] J. M. Asio and E. E. Riego de Dios, "The college students perspective on what makes an educator well-qualified," Journal of Pedagogical Research, vol. 3, no. 3, pp. 126-138, 2019.

[12] A. B. Yilmaz, "Distance and Face-To-Face Students' Perceptions towards Distance Education: A Comparative Metaphorical Study," Turkish Online Journal of Distance Education, pp. 191207, 2019.

[13] E. C. Jimenez, "Contextualized-E-Learning Resource A Tool for Stronger Academic Platform," SSRN, 10-Nov-2020. [Online]. Available: https://papers.ssrn.com/sol3/papers.cfm?abstract_id= 3696262. [Accessed: 20-Jul-2021].

[14] E. C. Jimenez, "Project N.E.W. - N.O.R.M.A.L. Navigating Electronic World to Numerous Online Resources of Modality Approaches in Learning," International Journal of Multidisciplinary: Applied Business and Education Research, vol. 2, no. 1, pp. 70-76, 2021. 
[15] J. M. Asio, E. Gadia, E. Abarintos, D. Paguio, and M. Balce, "Internet Connection and Learning Device Availability of College Students: Basis for Institutionalizing Flexible Learning in the New Normal," Studies in Humanities and Education, vol. 2, no. 1, pp. 56-69, 2021.

[16] J. M. R. Asio, "Disaster Management Program Compliance and Problems Encountered in Two Provinces in Central Luzon, Philippines," SSRN, 06-Jan-2021. [Online]. Available: https://papers.ssrn.com/sol3/papers.cfm?abstract_id=3723063. [Accessed: 20-Jul-2021].

[17] J. M. R. Asio, "Disaster Awareness and Level of Compliance to Disaster Programs in a Highly Urbanized City," Aquademia, vol. 5, no. 1, 2021.

[18] M. Akilli and H. K. Keskin, "The motivational factors affecting the preference of teaching profession in Turkey," Cogent Education, vol. 3, no. 1, p. 1240652, 2016.

[19] L. Simulwi and E. Musonda, "The Impact of Compulsory Computer Studies on ICT Literacy at Junior Secondary Schools in Livingstone District," International Journal of Information and Communication Technology Education, vol. 16, no. 4, pp. 20-34, 2020.

[20] S. Bayucca, "Teachers' Information and Communication Technology (ICT) Skills Assessment: Basis for a Comprehensive ICT Training Program," International Journal of Education, Science, Technology, and Engineering, vol. 3, no. 2, pp. 85-93, 2020. https://doi.org/10.36079/lamintang.ijeste-0302.160

[21] E. C. Jimenez, "Impact of Mental Health and Stress Level of Teachers to Learning Resource Development," Shanlax International Journal of Education, vol. 9, no. 2, pp. 1-11, 2021.

[22] E. E. Riego de Dios, "Emotional Intelligence and Work Values of Selected" [Online]. Available: https://files.eric.ed.gov/fulltext/ED605485.pdf. [Accessed: 20-Jul-2021].

[23] N. Arnold and L. Ducate, "Contextualized Views of Practices and Competencies in CALL" [Online]. Available: https://pdxscholar.library.pdx.edu/cgi/viewcontent.cgi?article=1012\&amp; context=ling_fac. [Accessed: 20-Jul-2021].

[24] J. M. R. Asio and E. C. Jimenez, "Professional Development, Organizational Climate, Supervisory Rapport and Overall Satisfaction of Employees: An Attitudinal Study," SSRN, 07Jul-2020. [Online]. Available: https://papers.ssrn.com/sol3/papers.cfm?abstract_id=3624812. [Accessed: 20-Jul-2021].

[25] E. C. Jimenez, "Emotional quotient, work attitude and teaching performance of secondary school teachers," Journal of Pedagogical Sociology and Psychology, vol. 2, no. 1, pp. 25-35, 2020. 